\title{
Adopter segments, adoption determinants and mobile marketing
}

Received (in revised form): 8th November, 2007

\section{Lieven De Marez}

is affiliated to the Department of Communication Sciences of the University of Ghent, with a PhD on segmentation forecasting and the diffusion and marketing of innovations. Currently, he is a senior researcher within the research groups MICT-IBBT and C.R.E.A.T.I.V.E.

\section{Patrick Vyncke}

is Professor of Communication Management at the Department of Communication Sciences - Ghent University - Belgium. He is also founder and head of the C.R.E.A.T.I.V.E. research centre, which focusses on advertising research.

\section{Katrien Berte}

is affiliated to the department of Communication Sciences of the University of Ghent, with a masters degree in communication sciences. Currently, she is a researcher within the research groups MICT-IBBT and C.R.E.A.T.I.V.E. Her research interests, publications and PhD research lie in the field of quantitative survey analysis, new media and advertising.

\section{Dimitri Schuurman}

works as a researcher at the Research Group for Media \& ICT (MICT-IBBT), Ghent University. His research focus is on the adoption and diffusion of new mobile technologies and gaming technologies.

\section{Katrien De Moor}

works as a researcher at the Research Group for Media \& ICT (MICT-IBBT), Ghent University. In this capacity, she is pursuing a PhD in user involvement and the importance of quality of experience/user experience in the development process of ICTs.

Keywords adoption determinants, targeting, mobile news, mobile television, segmentation forecasting

\begin{abstract}
Today's mobile ICT environment is an environment in which technology is evolving at a dazzling speed, in which consumers are overwhelmed with an ever-increasing amount of innovations at the device as well as the service level, and in which the supply-side's development and marketing departments are confronted with new challenges. In this environment, the success of innovations has become highly unpredictable and increasingly dependent on at least equally unpredictable attitudes towards the technology. One of the major challenges in today's highly competitive mobile ICT environment, coping with shortening product lifecycles and an increasing number of failing innovations, is the quest for more efficient introduction strategies in terms of more accurate segment targeting. In order to achieve this, the acquisition of a more accurate insight into adoption determinants has become an absolute prerequisite. To date, however, the literature and research on those determinants remain too fragmented to be a solid foundation for such research. Starting from a new comprehensive determinant model, we developed an item battery to measure the totality of possible determinants, and illustrate its application in two case studies on mobile innovations about to be introduced in Flanders: mobile news ( $n$ : 269) and mobile television (n: 405). Crossing such accurate attitudinal determinant insights with intention-based segmentation forecasts might provide mobile marketers with valuable input to set up more efficient mobile marketing and targeting campaigns in today's mobile ICT environment. Journal of Targeting, Measurement and Analysis for Marketing (2007) 16, 78-95. doi:10.1057/palgrave.jt.5750057; published online 7 January 2008
\end{abstract}

Correspondence: Lieven De Marez, Department of Communication Sciences, MICT-IBBT, C.R.E.A.T.I.V.E.,

Ghent University, Korte Meer 7-9-11, 9000 Gent, Belgium.

Tel: +32 926468 85; Fax: +32926468 92;

E-mail: Lieven.DeMarez@UGent.be 


\section{INTRODUCTION: TODAY'S ICT ENVIRONMENT}

'In this era of diminishing product life cycles and rapid technological advancements, it is critical for firms to identify and target innovation-prone consumers effectively. A clear understanding of the factors affecting consumers' adoption processes is crucial to the development of an effective marketing strategy. ${ }^{1}$

Today's ICT environment - and certainly the major mobile part of it — is a rapidly evolving market. Suppliers are confronted with diminishing product lifecycles ${ }^{2-4}$ and consumers are overwhelmed with an ever-increasing number of innovations. ${ }^{5-8}$ After the so-called 'digital revolution' initiating convergence between traditionally separated technologies, ${ }^{9,10}$ we are currently experiencing some kind of 'mobile revolution"11 in which all ICT and media usage seems to be going mobile. The wave of mobile telephony is largely behind us, but has created an environment in which every single person suddenly owns a personal 'mobile device' and everyone is always 'on' and reachable. Meanwhile, mobile technology converged with mp3, camera, gaming and other technologies, and several countries in Asia and Europe approached a mobile subscription rate close to (or even over) 100 per cent penetration. ${ }^{12}$ The consequence of the latter is that mobile operators are entering a new phase in which not only is the number of new subscribers lower but also the average revenue per user (ARPU) is declining, ${ }^{13}$ compelling them to look out for 'new revenue sources' as 'mobile internet', 14 'mobile news services', 'mobile television', ${ }^{15}$ etc.

Today's ICT environment has clearly become an environment in which we have evolved from triple (television, internet, telephony) towards 'quadruple play' ( + mobile), and in which consumers are confronted with an ever-increasing offer of (mobile) technologies, devices and services, also an environment in which the demand side is confronted with the danger of becoming overwhelmed by 'too much too soon ${ }^{16,17}$ and in which the success of innovations is becoming more and more dependent on 'attitudinal determinants' or attitudes towards technologies. ${ }^{18-22}$ In this environment, it has become crucial to target every consumer(s) segment(s) with the appropriate 'attitudinal' message(s).

Owing to the increasing number of failing innovations for which marketing is often taking the blame afterwards, ${ }^{23}$ marketing and introduction strategies have more than ever become 'one-shot opportunities' ${ }^{24}$ in this highly competitive environment. One of the key challenges in this quest for 'more efficient marketing' and better innovation introductions is the acquisition of a more accurate insight into attitudinal adoption determinants.

Or as Moreau et al. ${ }^{1}$ indicate in the abovementioned quote: efficient targeting ('it is critical to target innovation-prone consumers effectively') will be key to tackle that challenge. The high penetration rates of 'personal' mobile devices may be a valuable asset to do that, but the main prerequisite to make that targeting more efficient is an accurate identification of those consumers ('it will be critical to identify innovation-prone consumers') and an accurate insight into their 'attitudinal' adoption determinants ('a clear understanding of the factors affecting consumers' adoption processes').

\section{MARKETING IN TODAY'S ICT ENVIRONMENT}

If marketing is often taking the blame for failing innovations in today's ICT environment, this is because the traditional marketing approaches are not efficient enough in reaching the target audience. For the marketer in today's ICT environment, this implies two challenges:

(1) Through which paths can I reach the target audience(s) more efficiently? Traditional advertising and marketing approaches seem to have become insufficient, which results in an ongoing quest for new paths to do that more efficiently. In today's fragmented market environment, ${ }^{25,26}$ it is evident that traditional mass market (and mass media) approaches need to make way for a more differentiated and personalised approach of (micro)segment 
targeting. ${ }^{27,28}$ In order to achieve this, and given the fact that almost everyone has a personal mobile device, the advertising and marketing sector is rigorously experimenting with a diversity of new mobile marketing paths. Mobile opt-in programmes are commonly used to offer updates on promotions as lastminute travel offerings, and also as a return path to react on mass media campaigns advertisers are increasingly integrating mobiles in their campaigns. Some are experimenting with sms-to-mail campaigns (eg launch of 'Superman Returns' movie) in which people can send an sms to indicate their interest and receive additional information by mail. Others are experimenting with 'mobile billboard downloads ${ }^{29}$ or "profile and location based mobile ads' ${ }^{30}$

(2) With which messages can I reach the target audiences more efficiently? More efficient channels and communication paths will not suffice for a better marketing, however. Equally important at least for efficient micro-segment targeting is to have the correct arguments and messages to communicate to each of those microentities. ${ }^{31}$ And also, in this context, it is clear that the 'traditional approaches' cannot satisfy anymore. Innovator, early adopter, majority and laggard segments for different kinds of innovations for example, have always been associated with a typical 'archetype' or sets of profile assumptions in terms of demographics and attitudes towards new technologies, which are traditionally used to select and target the different types of adopter segments. ${ }^{32-34}$ When it comes to the targeting of innovators for example, marketing handbooks dictate that messages should be targeted at relatively young people, with a high level of income, education and social status, 35 and anticipate their typical attitudes towards new technologies (complexity not being a threshold, susceptible for social pressure, etc). In today's ICT environment, however, these profiles and assumptions have become too inconsistent ${ }^{36}$ to remain reliable as a basis for efficient targeting communications and discrimination between segments. ${ }^{18,37-40}$
As communication scientists, we mainly focus on the second challenge for today's (mobile) ICT marketer: more efficient (micro)segment targeting based on a detailed product- and segment-specific insight into communication arguments. The main area in which such an insight seems to be required is that of the 'attitudinal' adoption determinants.

\section{ADOPTION DETERMINANTS IN TODAY'S ICT ENVIRONMENT}

As 'traditional demographic characteristics' lost value over the years, 'attitudinal' adoption determinants have been put forward more as the alternative. ${ }^{18,20-22,41}$ 'Attitudinal determinants' stand for subjective perceptions of innovation characteristics and personality traits.

For a long time, the approach of these attitudinal adoption determinants was mainly inspired by diffusion theory, in which innovations were supposed to have a set of five characteristics (relative advantage, complexity, compatibility, trialability and observability), of which the subjective perception determines one's attitude towards the technology, and one's innovativeness or timing of adoption decision. ${ }^{42-44}$ The assumptions on the relationship between innovativeness and adoption determinants in terms of perceived innovation characteristics are summarised in Table 1. As indicated by the + or - signs, the perception of each of these innovation characteristics is assumed to have a fixed relationship with one's innovativeness. The more one perceives a relative advantage or the less one perceives the innovation as complex, the more one is assumed to be innovative for the specific technology. Innovators and early adopters are assumed to have a higher perception of relative advantage than the majority segments and a lower complexity perception. These determinant assumptions often serve as a basis for communication strategies when introducing innovations, ${ }^{57}$ or as the framework for methodologies to detect innovativeness and adopter segments.

Over the years, the increasing attention paid to these 'attitudinal' adoption determinants resulted in a considerable yet cluttered extension of the original set of five adoption determinants. The 
Table 1: Diffusion theory: Assumption on adoption determines

\begin{tabular}{|c|c|c|c|}
\hline \multirow{2}{*}{$\begin{array}{l}\text { Adoption } \\
\text { determinant }\end{array}$} & \multicolumn{2}{|c|}{ Assumption } & \multirow{2}{*}{$\begin{array}{l}\text { References } \\
\begin{array}{l}\text { Rogers (2003: 229, 265) } \\
\text { Karahanna et al. Sameer (1999: 188) }{ }^{46} ; \ldots\end{array}\end{array}$} \\
\hline & $(+)$ & $\begin{array}{l}\text { Positive correlation: the more an innovation is } \\
\text { perceived as better than its alternatives or the } \\
\text { idea it supersedes, the more innovative it is }\end{array}$ & \\
\hline $\begin{array}{l}\text { Perceived } \\
\text { complexity }\end{array}$ & $(-)$ & $\begin{array}{l}\text { Negative correlation, the more an innovation } \\
\text { is perceived as relatively difficult to understand } \\
\text { and use, the less innovative it is }\end{array}$ & $\begin{array}{l}\left.\text { Rogers (2003: } 266)^{42} \text {; Davis (1989: } 340\right)^{47} \text {; Plouffe } \\
\text { et al. }(2001: 68)^{20} \text {; Chang and Cheung }(2001: 5)^{48} \text {; } \\
\text { Servaes and Heinderyckx }(2002: 105)^{49} ; \\
\text { Chen et al. }(2002: 708)^{37} ; \ldots\end{array}$ \\
\hline $\begin{array}{l}\text { Perceived } \\
\text { trialability }\end{array}$ & $(+)$ & $\begin{array}{l}\text { Positive correlation, the more there can be } \\
\text { experimentation with the innovation on a } \\
\text { limited basis, the more innovative it is }\end{array}$ & $\begin{array}{l}\text { Rogers (2003: 265) }{ }^{42} \text {; Choi et al. }(2003: 169)^{8} ; \\
\quad \text { Heres et al. }(2002: 57)^{50} \text {, Dowling (1999: 112) }{ }^{51} ; \ldots\end{array}$ \\
\hline $\begin{array}{l}\text { Perceived } \\
\text { compatibility }\end{array}$ & $(+)$ & $\begin{array}{l}\text { Positive correlation, the more one perceives } \\
\text { the innovation as consistent with the existing } \\
\text { values, experiences and needs, the more } \\
\text { innovative it is }\end{array}$ & $\begin{array}{l}\text { Rogers (2003: 266) })^{42} \text {; Lin }(2003: 354)^{38} \\
\text { Brown et al. }(2003: \text { 384) } \\
(2002: \text {; } 19)^{53} . \text { Guiltinan }(1999: 30)^{54} ; \ldots\end{array}$ \\
\hline $\begin{array}{l}\text { Perceived } \\
\text { observability }\end{array}$ & $(+)$ & $\begin{array}{l}\text { Positive correlation, the more the results of } \\
\text { the (use of the) innovation are perceived to be } \\
\text { visible to others, the more innovative it is }\end{array}$ & $\begin{array}{l}\text { Rogers (2003: } 266)^{42} \text {; Lin }(2003: 354)^{38} \text {; } \\
\text { Meijer et al. }(2002: 2)^{55}, \text { Easingwood and Lunn } \\
(1992: 74-75)^{56} ; \ldots\end{array}$ \\
\hline
\end{tabular}

convergence with social psychology theories such as the Theory of Reasoned Action (TRA), ${ }^{58,59}$ Technology Adoption Model (TAM) ${ }^{60,47}$ and (Decomposed) Theory of Planned Behavior $((\mathrm{D}) \mathrm{TPB})^{61,62}$ in particular led to an extremely valuable - yet fragmented - increase in (research on) adoption and determinant models. Some consider one or two extra determinants, ${ }^{63}$ while others considered eight, ${ }^{20} \operatorname{ten}^{8}$ or more determinants.

\section{COMPRISING MODEL OF DETERMINANTS}

Before focusing on 'gaining the necessary insight in those determinants', one is confronted with the problem of a 'lack of overview', since the increased multidisciplinary interest entails a cluttered and inconveniently arranged entirety of determinants. Evidently, good marketing communication requires an insight into more than the five determinants of Rogers' diffusion theory, but it remains unclear in how many and which determinants this insight is actually required. Since a convenient overview of (potentially) relevant adoption determinants for ICT innovations is still lacking to date, ${ }^{64-66}$ we conducted a meta-analysis of determinants for ICT adoption, starting from studies and theories ${ }^{67}$ whose central building block was diffusion theory's set of five determinants. This resulted in an extension to 19 determinants, in which we distinguish ten innovation-related characteristics (perceptions), eight adopter-related characteristics and the impact of the marketing strategy (Table 2).

Clearly, innovativeness and adoption decisions seem to be determined by more determinants than the original five initiated by Rogers' diffusion theory. The perception of relative advantage for example, can express itself in several dimensions. The perceived cost and tangibles/ aesthetics are the most important of them. Most followed Rogers in his conceptualisation of observability in terms of the perceived result demonstrability, but some distinguish the latter from 'visibility' as the degree to which the innovation is visible to others in its own right. It is also important to account for the perceived enjoyment of using the innovation, and 'reliability' as a dimension of perceived risk that is not covered by other determinants. ${ }^{105}$ Innovativeness, on the other hand, is the most important personality trait. It covers a multitude of subdimensions such as 'venturesomeness', 'novelty seeking', 'cosmopolitanism', 'variety seeking', 'information seeking', etc. Opinion-leadership needs to be considered as a separate dimension, 
Table 2: Extension of adoption determines

\begin{tabular}{|c|c|c|}
\hline $\begin{array}{l}\text { Adoption } \\
\text { determinant }\end{array}$ & $\begin{array}{l}\text { Assumed } \\
\text { relationship with } \\
\text { innovativeness }\end{array}$ & References \\
\hline \multicolumn{3}{|c|}{ Innovation-related characteristics } \\
\hline Relative Advantage & + & $\begin{array}{l}\text { Rogers (2003: 229, 265) }{ }^{42} \text {; Sameer (1999: 20) }{ }^{45} \text {; Karahanna et al. (1999: 188) } \\
\text { Lin (2003: } 354)^{38} \text {; Bouwman et al. }(2002: 19)^{53}\end{array}$ \\
\hline Cost & - & $\begin{array}{l}\text { Easingwood and Lunn (1992: 74) })^{56}, \text { Heres et al. }(2002: 57)^{50} \\
\text { Servaes and Heinderycks }(2002: 105)^{49} \text {, Fliegel and Kivlin }(1966)^{68} \text {, } \\
\text { Cestre and Darmon (1998: } 125)^{69}\end{array}$ \\
\hline Tangibles & + & $\begin{array}{l}\text { Veryzer (1998: } 136)^{70} \text {; Chan-Olmsted Gershon }(2001: 284)^{71} \\
\text { Heres et al. }(2002: 57)^{50} \text {, Punie (2000: 422) }\end{array}$ \\
\hline Complexity & - & $\begin{array}{l}\left.\text { Rogers (2003: 266) }{ }^{42} \text {; Davis (1989: 340) }\right)^{47} \text {; Plouffe et al. }(2001: 68)^{20} \\
\text { Chang and Cheung (2001: 5) }\end{array}$ \\
\hline Trialability & + & $\begin{array}{l}\text { Rogers (2003: 265) }{ }^{42} \text {; Choi et al. }(2003: 169)^{8} \text {; Heres et al. }(2002: 57)^{50} \text {; } \\
\text { Dowling (1999: 112) })^{51} ; \text { Frambach and Hillebrand (1994: 38) }\end{array}$ \\
\hline Compatibility & + & $\begin{array}{l}\text { Rogers (2003: 266) }{ }^{42} \text {; Lin }(2003: 354)^{38} \text {; Brown et al. }(2003: 384)^{52} \\
\text { Bouwman et al. }(2002: 19)^{53} \text {, Guiltinan (1999: 30) }{ }^{54} \text {; Meijer et al. }(2002: 2)^{55}\end{array}$ \\
\hline Observability & + & $\begin{array}{l}\left.\text { Rogers (2003: 266) }{ }^{42} \text {; Lin (2003: 354) }\right)^{38} \text {; Meijer et al. }(2002: 2)^{55} \text {, Easingwood and } \\
\text { Lunn (1992: 74-75) }{ }^{56} \text {; Bouwman et al. }(2002: 20)^{53}\end{array}$ \\
\hline Visibility & + & Heres et al. (2002: 57) ${ }^{50}$, Karahanna et al. (1999: 188) ${ }^{46}$; Plouffe et al. $(2001: 68)^{20}$ \\
\hline Enjoyment & + & $\begin{array}{l}\text { Choi et al. (2003: 168) }{ }^{8} \text {, Chang and Cheung }(2001: 2)^{48}, \text { Randolph (1999: 738) } \\
\text { Igbaria et al., 1996: } 128^{74} \text {; Mundorf and Westin (1996) }\end{array}$ \\
\hline Reliability & + & $\begin{array}{l}\text { Frambach and Hillebrand (1994: 38) }{ }^{73} \text {; Ram and Sheth (1989: 8) } \\
\text { Dodgson (2000: 99) } \\
\text { Do } \text {, Eastin (2002: 252) }\end{array}$ \\
\hline \multicolumn{3}{|l|}{$\begin{array}{l}\text { Adopter-related } \\
\text { characteristics }\end{array}$} \\
\hline Innovativeness & + & $\begin{array}{l}\text { Dowling (1978: 235) }{ }^{79} \text {; Hirschman (1980: 285) }{ }^{80} \text {, Li (2004: 187) } \\
\text { Jeffres, Atkin Nenendorf, 1998: 485) }\end{array}$ \\
\hline Opinion leadership & + & $\begin{array}{l}\text { Oxley and Nancorrow (2003: 40) })^{34} \text {; Frambach and Hillebrand (1994: 41) } \\
\text { Lin (2003: 352) }\end{array}$ \\
\hline (Product) knowledge & + & $\begin{array}{l}\text { Atkin et al. (2003: 161) }{ }^{19} \text {; Gatignon and Robertson (1989: 25) } \\
\text { and Markman (2001: } 27)^{1} \text {, Fichman and Kemerer (1997: 1345) }\end{array}$ \\
\hline Optimism & + & $\begin{array}{l}\text { Parasuraman and Colby }(2001)^{87} \text {, Wei }(2001)^{88} \text {, Neuendorf et al. }(1998: 83)^{89} \text {; } \\
\text { Punie (2000: } 215)^{72}\end{array}$ \\
\hline Image/Prestige & + & $\begin{array}{l}\left.\text { Choi et al. (2003: 168) }{ }^{8} \text {, Rogers (2003: 230 }\right)^{42} \text {, Plouffe et al. }(2001: 68)^{20} \text {, } \\
\text { Moore and Benbasat }(1991: 195)^{90} \text {, Sheth et al. }(1991: 161)^{91}\end{array}$ \\
\hline Willingness to pay & + & $\begin{array}{l}\text { Talukdar et al. (2002: 102) })^{92} \text {, Jiang (2002: 181) }{ }^{93} \text {, Ricci, }(2000: 156)^{94} \text {, Busselle et al. } \\
\text { (1999: 46) })^{64} \text {; Lennstrand (1998a: 8) }{ }^{95} \text {, Gatignon and Robertson (1989: 25) }\end{array}$ \\
\hline Control, voluntariness & + & $\begin{array}{l}\text { Venkatesh (2000: 346) })^{96} \text {, Lee and Baek (2001: 1) }{ }^{97} \text {, Randolph (1999: 739) } \\
\text { Eastin (2002: } 255)^{40} \text {, Pajo (2000: 2) }\end{array}$ \\
\hline Social influence & + & $\begin{array}{l}\text { Choi et al. }(2003)^{8}, \text { Karahanna et al. }(1999: 187)^{46} \text {, Taylor and Todd }(1995)^{62} \text {, } \\
\text { Lau et al. }(2001: 60)^{99} \text {, Fishbein and Ajzen }(1975: 302)^{59}\end{array}$ \\
\hline Marketing (impact) & + & $\begin{array}{l}\text { Steenkamp and Gielens (2003: 380) })^{100} \text {, Jankowski and Van Selm }(2001: 222)^{101} \text {, } \\
\text { Bouwman and De Jong (1996: 166) }{ }^{102} \text {, Sultan et al. }(1990)^{103}, \\
\text { Gatignon and Robertson }(1985: 850)^{104}\end{array}$ \\
\hline
\end{tabular}


just as a person's optimism towards technology, product knowledge, willingness (and ability) to pay, the perceived impact on one's personal image, the perceived control, impact of social influences and the impact of marketing, advertising and promotional strategies.

If a good targeting and marketing communication in today's (mobile) ICT environment requires an insight into more than the traditional five determinants, it will largely boil down to an insight into these 19 determinants. It will probably never be the case that all these determinants are relevant, but if prior-to-launch research could reveal which determinants are the most important drivers and thresholds for which segments, this would allow to adjust the targeting communications (eg by emphasising the 'status impact' and 'perceived enjoyment' for one segment, while tackling 'voluntariness' or 'complexity' — perceptions and - thresholds for the other).

Just as this is the case for other profiling variables (eg sociodemographics) (see discussion above), a growing number of studies are also revealing an increasing inconsistency for these determinant assumptions. ${ }^{20,64,106,107}$ The assumed relationship with a person's innovativeness is certainly not always confirmed, and dependent on the innovation being the subject of research, it is, often quite, different determinants that are the significant determinants of the adoption decision. Hence, also for these attitudinal determinants, one cannot afford anymore to start from generalising assumptions and profiles. Therefore, the required insight into determinants can be specified to a need for a product-specific insight into determinants. If we also account for the earlier remark that more efficient marketing communication also implies more (micro)segment targeting, we can even specify this to a 'need for product- and segment-specific insight in determinants'.

The question, however, remains as to how to acquire such an insight.

\section{CASE STUDIES AND METHODOLOGY}

The above-mentioned question was also the central question in two recent case studies conducted by the MICT-IBBT research group. ${ }^{108}$ Both studies were set up to acquire the necessary insight into attitudinal adoption determinants for two 'mobile innovations', as a basis for their introduction in Belgium (i.t.o. marketing and targeting campaign). In the first case study (2006), a sample of 269 respondents was questioned on their attitude towards a new 'mobile news' - application in the context of the IBBT-Romas ${ }^{109}$ project. In the second case study (2007), a representative Flemish sample of 405 respondents was questioned on their attitude towards mobile television services. In the first study, data were collected by means of an online survey (after two months, during which the respondents could test the mobile news application). In the second study, data were collected by means of 40-min CAPI interviews (in which respondents were shown DVDfragments in order to familiarise them with mobile television applications and usage moments).

Methodologically, each of the studies had to tackle the same 'double question': (a) in the first instance, gaining a prior-to-launch insight into the different (potential) adopter segments for the new mobile application; and secondly (b) gaining an insight into the attitudinal adoption determinants for each of those technologyspecific segments.

The first challenge was tackled by means of an intention survey method: the Product Specific Adoption Potential (PSAP) scale. For the second question, the 19 determinants were operationalised in a battery of 47 Likert statements (cf. Table 3), to be answered on five-point agreement scales.

The PSAP scale is an intention-based survey method in which respondents are allocated to innovator, early adopter, majority and laggard segments based on the stated intentions on a general intention question and on respondentspecific formulated questions gauging their intention for 'optimal' and 'suboptimal' product offerings. ${ }^{110-113}$ The operationalisation of determinants into a scale of 47 items is the combined result of desk and focus group research. A first phase of desk research resulted in a long 
Table 3: Operationalisation of determinants in 47 Likert statements

Compatibility - lifestyle and personality

7. Consultation of Mobile news/TV services fits my lifestyle

39. If I buy a new mobile, it has to be a model that fits my personality

\section{Compatibility - (Technological)}

30. I am interested in subscribing to mobile news/TV services? but I would mind if that would imply an investment in a new device.

13. Mobile news/TV services are only interesting to me as a part of the subscription on other mobile services.

\section{Relative Advantage}

11. The advantages of mobile news/TV services are clearer to me than the disadvantages.

40. I don't see where or when to use mobile news/TV services.

\section{Cost (Relative Advantage)}

Subscription on mobile news/TV services seems

1. expensive to me.

5. Mobile news/TV services will probably cost too much for many people.

\section{Tangibles (Relative Advantage)}

25. As the mobile news/TV services is presented and testable now it has an attractive design and style.

14. If I would consider buying a new mobile, design would be a very important buying argument to me.

\section{Effectiveness (Relative Advantage)}

Mobile news/TV services will certainly make some

36 things easier for me.

\section{Trialability - Physical}

41. I would like to try out mobile news/TV services before subscribing to them.

Trialability - Vicarious

28. Before subscribing or adopting mobile news/TV services I prefer to look around for a while and see how others are experiencing the application.

Observability - visibility

12. One of the nice things of a mobile news/TV application is that it is something to show off with among friends.

17. I see many people in my environment who use mobile news/TV services.

\section{Marketing strategy}

26. If I would subscribe to a mobile news/TV application, it would be important to me that it is provided by a wellknown 'brand'.

27. If I would consider mobile news/TV adoption, I would first check the ads, brochures and promotions.

\section{Innovativeness}

6. I think to be among the first to subscribe to such mobile news/TV services.

34. Based on what I already knew about the application and what I have learned today, I will certainly search for more information about subscribing to these services.

\section{Opinion Leadership}

15. If mobile news/TV would be introduced on the market, people in my environment will certainly come to me for advice.

Product Knowledge

19. I recently send something about mobile news/TV services or recently talked to someone about it.

35. I consider myself well-informed about the possibilities and (dis)advantages of mobile news/TV services.

Optimism

44. The fast technological developments are a good thing.

45. If you don't want to run behind, adoption of new technologies is necessary.

\section{Image Prestige}

33. Subscribing to mobile news/TV services applications would have a positive impact on my image and social status.

38. Subscribing to mobile news/TV services beams out a certain standing.

\section{Willingness-to-pay}

22. Even if it costs a bit more, mobile news/TV is something I really want.

\section{Control/Self-efficacy}

46. I have no problem to sort out on myself how mobile news/ TV application work and must be installed.

\section{Voluntariness}

42. If I would subscribe to mobile news/TV services, it would completely be my own decision. No one would influence me in making that decision.

\section{Social influence}

9. Most people in my environment will certainly be enthusiast about the mobile news/TV application. 
Table 3: Continued

\begin{tabular}{|c|c|c|c|}
\hline 24. & $\begin{array}{l}\text { Observability - Result Demonstrability/ } \\
\text { Communicability } \\
\text { I am perfectly able to explain the strengths and } \\
\text { the weakness of mobile news/TV services to } \\
\text { others }\end{array}$ & 37. & $\begin{array}{l}\text { Social influence - network externalities } \\
\text { I am interested in subscribing to mobile news/TV } \\
\text { services, but only if there are sufficient people in my direct } \\
\text { environment doing so. Otherwise, the application wouldn't } \\
\text { have much value to me. }\end{array}$ \\
\hline 4. & $\begin{array}{l}\text { Enjoyment } \\
\text { Mobile news/TV service seems very user friendly } \\
\text { to me. }\end{array}$ & 3. & $\begin{array}{l}\text { Social influence - interpersonal communications } \\
\text { Before subscribing to a mobile news/TV application, I } \\
\text { would like the advice of some people. }\end{array}$ \\
\hline 8. & $\begin{array}{l}\text { Complexity/Comfort Level } \\
\text { I fear that mobile new/TV services application } \\
\text { offers different possibilities, which makes It rather } \\
\text { complicated. }\end{array}$ & 16. & $\begin{array}{l}\text { Mobile news/TV services will certainly be a topic of } \\
\text { discussion among my friends and family. }\end{array}$ \\
\hline 20. & $\begin{array}{l}\text { The mobile news services application seems very user- } \\
\text { friendly to me. } \\
\text { The mobile news/TV services application offers different } \\
\text { possibilities, which makes it rather complicated. }\end{array}$ & 2. & $\begin{array}{l}\text { Social influence - Compliance } \\
\text { If 'mobile news/TV usage' would be considered as } \\
\text { 'trendy' in my environment, I would certainly consider } \\
\text { subscribing to it. }\end{array}$ \\
\hline 31. & $\begin{array}{l}\text { Reliability } \\
\text { I doubt the reliability and proper functioning of } \\
\text { the mobile news/TV services application. }\end{array}$ & 32. & $\begin{array}{l}\text { My direct environment will probably expect me to be one } \\
\text { of the first to use mobile news/TV services. } \\
\text { Even if I am interested, I would not subscribe if my } \\
\text { environment would be negative about mobile news/TV } \\
\text { applications. }\end{array}$ \\
\hline 18. & $\begin{array}{l}\text { Perceived Risk (financial) } \\
\text { I fear that subscribing to a mobile news/TV application } \\
\text { would be way above my budget. }\end{array}$ & 47. & $\begin{array}{l}\text { Social influence - Identification } \\
\text { If I would use mobile news/TV services, it would certainly } \\
\text { tell something about me and my personality. }\end{array}$ \\
\hline 21. & $\begin{array}{l}\text { Perceived Risk (social) } \\
\text { If I would use mobile news/TV services, people in my } \\
\text { environment would look odd at me. }\end{array}$ & & \\
\hline 23. & $\begin{array}{l}\text { Perceived Risk (implementation) } \\
\text { If I would have to use such mobile news/TV } \\
\text { applications on my own, I don't think I would manage. }\end{array}$ & & \\
\hline
\end{tabular}

list of operationalisations of the 19 determinants in other studies and models. ${ }^{8,20,48,62,63,87,90,104,114-116}$ In the second phase, this long list was verified in four focus group discussions in order to select the best operationalisations. ${ }^{117}$

\section{RESULTS}

With the purpose of acquiring the necessary insight into attitudinal adoption determinants for the preparation of introduction, marketing and targeting strategies for both mobile applications, each of the 269 (mobile news study) and 405 (mobile television) respondents was asked to evaluate the 47 items on a 5-point Likert scale, ranging from 1: 'Completely disagree' to 5: 'totally agree' (Table 4).
Table 5 reports on two types of analysis on those data: (a) a comparison of mean agreement scores between adopter segments (one-way ANOVA, analysis of variances and mean scores) in order to detect differences in attitudes towards the new technologies; and (b) regression analysis of the determinants on the respondents' adoption intention, in order to detect up to which degree these attitudes are correlated with the adoption intention. The combination of both analyses should provide a valuable input for more effective segment and technology-specific marketing and targeting communication strategies when introducing both new mobile applications.

The PSAP method revealed a larger potential for the mobile news application in Flanders than for 
桨 De Marez et al.

Table 4: Segmentation forecasts for Mobile Television and Mobile News in Flanders

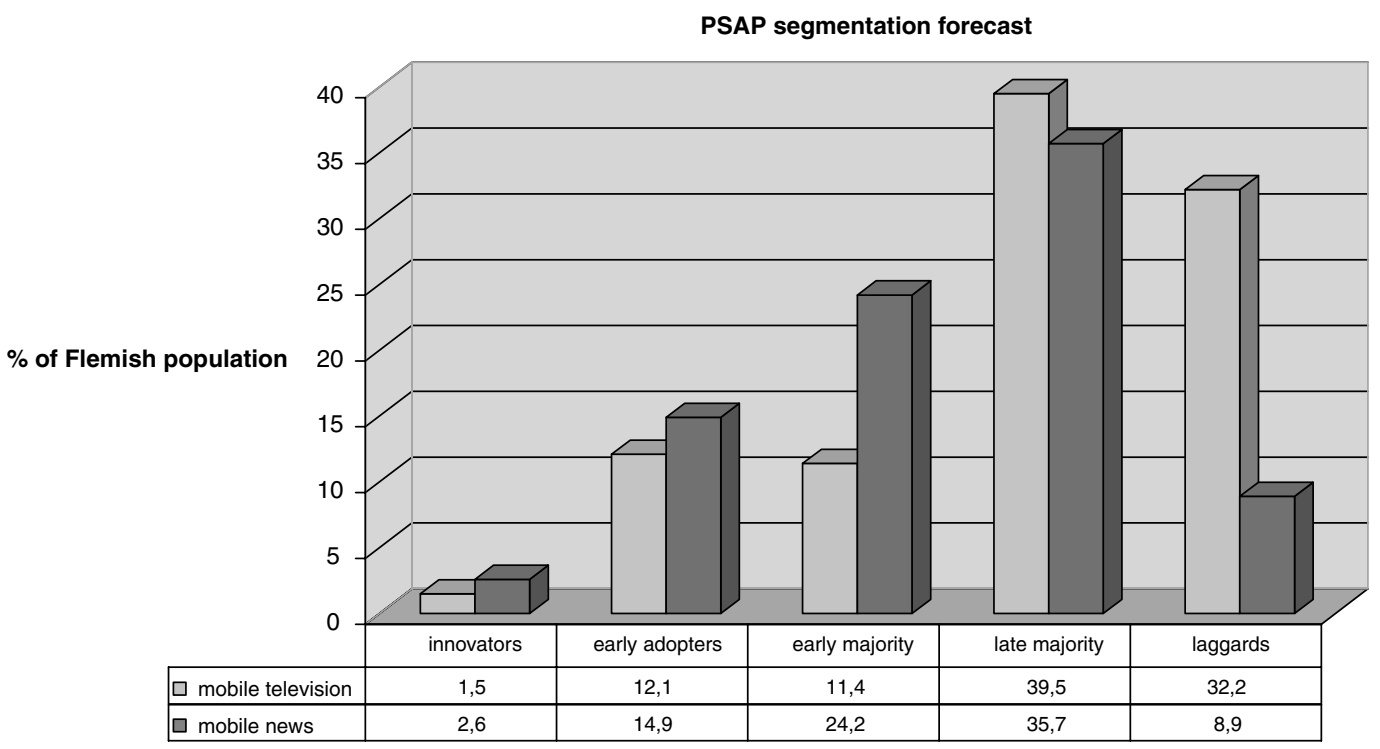

Table 5: Adoption determinants for Mobile News and Mobile Television. Comparison of mean agreement scores (ANOVA) and regression on adoption intention

\begin{tabular}{|c|c|c|c|c|c|c|c|}
\hline & \multicolumn{4}{|c|}{ (a) ANOVA } & \multicolumn{3}{|c|}{ (b) Regression analysis } \\
\hline & \multicolumn{4}{|c|}{ Mean comparison (1: Completely disagree -5 : Totally agree) } & \multicolumn{3}{|c|}{ Regression weights } \\
\hline & $\begin{array}{l}\text { Earlier } \\
\text { adopters }\end{array}$ & $\begin{array}{l}\text { Early } \\
\text { majority }\end{array}$ & $\begin{array}{l}\text { Later } \\
\text { adopters }\end{array}$ & $p$-value & $\begin{array}{l}\text { EA } R^{2}: 0.795 \\
0.641\end{array}$ & $\begin{array}{l}\text { EM } R^{2}: 0.503 \\
0.591\end{array}$ & $\begin{array}{l}\text { LA } R^{2}: 0.424 \\
0.343\end{array}$ \\
\hline \multirow[t]{2}{*}{1.} & 3.20 & 3.85 & 3.81 & 0.001 & NS & NS & NS \\
\hline & 3.36 & 3.65 & 4.02 & 0.000 & NS & NS & $-0.104(\mathrm{~S})$ \\
\hline \multirow[t]{2}{*}{2.} & 2.36 & 2.11 & 2.01 & 0.116 & NS & NS & NS \\
\hline & 3.13 & 2.76 & 1.93 & 0.000 & NS & NS & $-0.125(\mathrm{~S})$ \\
\hline \multirow[t]{2}{*}{3.} & 2.43 & 2.80 & 2.89 & 0.092 & NS & NS & NS \\
\hline & 3.53 & 3.30 & 3.62 & 0.0387 & NS & NS & NS \\
\hline \multirow[t]{2}{*}{4.} & 3.70 & 3.50 & 3.25 & 0.015 & NS & NS & NS \\
\hline & 4.09 & 3.70 & 2.85 & 0.000 & NS & NS & $-0.143(\mathrm{~S})$ \\
\hline \multirow[t]{2}{*}{5.} & 3.55 & 3.73 & 3.79 & 0.323 & NS & NS & NS \\
\hline & 3.87 & 4.13 & 4.09 & 0.345 & NS & NS & NS \\
\hline \multirow[t]{2}{*}{6.} & 3.34 & 2.48 & 2.08 & 0.000 & NS & NS & $-0.309(\mathrm{~S})$ \\
\hline & 2.80 & 2.28 & 1.44 & 0.000 & NS & NS & NS \\
\hline \multirow[t]{2}{*}{7.} & 3.81 & 3.30 & 2.89 & 0.000 & NS & NS & NS \\
\hline & 2.95 & 2.93 & 1.68 & 0.001 & NS & NS & NS \\
\hline \multirow[t]{2}{*}{8.} & 2.11 & 2.48 & 2.40 & 0.146 & NS & NS & NS \\
\hline & 2.47 & 2.43 & 2.60 & 0.623 & NS & NS & NS \\
\hline \multirow[t]{2}{*}{9.} & 3.16 & 2.90 & 2.76 & 0.026 & NS & NS & NS \\
\hline & 3.51 & 3.09 & 2.59 & 0.000 & NS & NS & NS \\
\hline \multirow[t]{2}{*}{10.} & 3.73 & 3.16 & 2.83 & 0.000 & NS & NS & NS \\
\hline & 2.56 & 2.33 & 1.59 & 0.000 & NS & NS & NS \\
\hline \multirow[t]{2}{*}{11.} & 3.55 & 3.13 & 2.98 & 0.003 & NS & NS & NS \\
\hline & 3.18 & 2.98 & 2.20 & 0.000 & NS & NS & 0.092 (S) \\
\hline \multirow[t]{2}{*}{12.} & 2.64 & 2.19 & 2.10 & 0.020 & NS & NS & NS \\
\hline & 2.82 & 2.28 & 1.83 & 0.000 & 0.247 (S) & NS & NS \\
\hline \multirow[t]{2}{*}{13.} & 3.73 & 3.52 & 3.31 & 0.070 & NS & NS & NS \\
\hline & 3.38 & 4.02 & 3.45 & 0.012 & NS & NS & NS \\
\hline \multirow[t]{2}{*}{14.} & 3.55 & 3.38 & 3.60 & 0.488 & $0.362(\mathrm{~S})$ & NS & $0.182(\mathrm{~S})$ \\
\hline & 3.47 & 3.74 & 2.99 & 0.001 & 0.256 (S) & NS & NS \\
\hline \multirow[t]{2}{*}{15.} & 3.68 & 3.37 & 3.26 & 0.079 & NS & NS & NS \\
\hline & 3.16 & 2.63 & 2.12 & 0.000 & $0.179(\mathrm{~S})$ & NS & NS \\
\hline \multirow[t]{2}{*}{16.} & 3.34 & 3.11 & 2.84 & 0.017 & NS & NS & NS \\
\hline & 3.11 & 3.09 & 2.26 & 0.000 & NS & NS & NS \\
\hline
\end{tabular}


Table 5: Continued

\begin{tabular}{|c|c|c|c|c|c|c|c|}
\hline & (a) ANOVA & & & & (b) Regressio & inalysis & \\
\hline & Mean com & son (1: Co & etely disag & $-5:$ Totally agree) & Regression $\mathrm{w}$ & ghts & \\
\hline & $\begin{array}{l}\text { Earlier } \\
\text { adopters }\end{array}$ & $\begin{array}{l}\text { Early } \\
\text { majority }\end{array}$ & $\begin{array}{l}\text { Later } \\
\text { adopters }\end{array}$ & $p$-value & $\begin{array}{l}\text { EA } R^{2}: 0.795 \\
0.641\end{array}$ & $\begin{array}{l}\text { EM } R^{2}: 0.503 \\
0.591\end{array}$ & $\begin{array}{l}\text { LA } R^{2}: 0.424 \\
0.343\end{array}$ \\
\hline 17. & 2.70 & 2.43 & 2.15 & 0.006 & NS & NS & $-0.215(\mathrm{~S})$ \\
\hline & 2.67 & 2.59 & 2.04 & 0.000 & NS & NS & NS \\
\hline 18. & 2.93 & 2.94 & 3.21 & 0.106 & NS & NS & NS \\
\hline & 2.73 & 2.85 & 3.18 & 0.029 & NS & NS & NS \\
\hline 19. & 2.57 & 2.65 & 2.50 & 0.735 & $0.214(\mathrm{~S})$ & NS & NS \\
\hline & 2.09 & 1.63 & 3.18 & 0.001 & NS & NS & NS \\
\hline 20. & 3.86 & 3.48 & 3.43 & 0.013 & $0.565(\mathrm{~S})$ & NS & NS \\
\hline & 3.33 & 3.63 & 3.14 & 0.017 & NS & NS & NS \\
\hline 21. & 2.00 & 2.08 & 2.11 & 0.733 & NS & $-0.467(\mathrm{~S})$ & NS \\
\hline & 2.29 & 2.04 & 2.68 & 0.004 & NS & NS & NS \\
\hline 22. & 2.64 & 2.18 & 1.90 & 0.000 & NS & NS & NS \\
\hline & 3.00 & 2.52 & 1.53 & 0.000 & NS & NS & NS \\
\hline 23. & 2.05 & 2.21 & 2.20 & 0.612 & NS & $-0.260(\mathrm{~S})$ & NS \\
\hline & 2.60 & 2.11 & 2.29 & 0.178 & NS & NS & NS \\
\hline 24. & 3.89 & 3.56 & 3.39 & 0.022 & NS & NS & NS \\
\hline & 2.87 & 3.04 & 2.72 & 0.284 & $0.181(\mathrm{~S})$ & NS & NS \\
\hline 25. & 3.18 & 3.00 & 2.85 & 0.093 & NS & NS & NS \\
\hline & 3.45 & 3.61 & 3.34 & 0.250 & NS & NS & NS \\
\hline 26. & 4.05 & 3.93 & 3.75 & 0.104 & NS & NS & NS \\
\hline & 3.29 & 3.63 & 3.20 & 0.152 & NS & NS & NS \\
\hline 27. & 3.45 & 3.70 & 3.74 & 0.178 & NS & NS & NS \\
\hline & 3.85 & 4.17 & 4.13 & 0.183 & NS & NS & NS \\
\hline 28. & 2.79 & 3.46 & 3.67 & 0.000 & NS & NS & NS \\
\hline & 3.40 & 3.89 & 3.92 & 0.008 & NS & NS & NS \\
\hline 29. & 2.07 & 2.26 & 2.41 & 0.161 & NS & NS & $-0.184(\mathrm{~S})$ \\
\hline & 2.75 & 2.28 & 2.77 & 0.070 & $0.166(\mathrm{~S})$ & NS & NS \\
\hline 30. & 3.16 & 3.70 & 3.86 & 0.001 & NS & NS & $-0.168(S)$ \\
\hline & 3.33 & 3.34 & 3.47 & 0.778 & NS & NS & NS \\
\hline 31. & 2.28 & 2.41 & 2.58 & 0.208 & NS & NS & NS \\
\hline & 2.69 & 2.70 & 2.91 & 0.308 & NS & NS & NS \\
\hline 32. & 1.86 & 2.05 & 2.21 & 0.111 & NS & NS & NS \\
\hline & 2.67 & 2.33 & 2.38 & 0.296 & NS & NS & NS \\
\hline 33. & 2.47 & 2.28 & 2.20 & 0.298 & $0.483(\mathrm{~S})$ & NS & $-0.230(\mathrm{~S})$ \\
\hline & 2.47 & 2.22 & 1.60 & 0.000 & NS & NS & NS \\
\hline 34. & 3.14 & 2.70 & 2.47 & 0.000 & NS & NS & NS \\
\hline & 3.27 & 3.00 & 2.09 & 0.000 & NS & NS & NS \\
\hline 35. & 3.55 & 3.36 & 3.19 & 0.100 & $0.427(\mathrm{~S})$ & NS & NS \\
\hline & 2.98 & 2.76 & 2.64 & 0.158 & NS & NS & NS \\
\hline 36. & 3.63 & 3.23 & 2.93 & 0.000 & NS & NS & NS \\
\hline & 3.36 & 2.87 & 1.95 & 0.000 & NS & NS & NS \\
\hline 37. & 2.12 & 2.08 & 2.05 & 0.897 & NS & NS & NS \\
\hline & 2.15 & 2.09 & 1.75 & 0.011 & NS & NS & NS \\
\hline 38. & 2.41 & 2.25 & 2.19 & 0.496 & 0.862 (S) & NS & NS \\
\hline & 2.69 & 2.67 & 1.89 & 0.000 & 0.227 (S) & NS & NS \\
\hline 39. & 3.05 & 3.30 & 3.13 & 0.567 & NS & NS & NS \\
\hline & 2.82 & 2.65 & 2.16 & 0.001 & $0.366(\mathrm{~S})$ & NS & NS \\
\hline 40. & 1.84 & 2.28 & 2.60 & 0.000 & NS & NS & NS \\
\hline & 2.13 & 2.41 & 3.34 & 0.000 & NS & NS & NS \\
\hline 41. & 4.23 & 4.07 & 4.23 & 0.427 & NS & $0.356(\mathrm{~S})$ & NS \\
\hline & 4.18 & 4.11 & 3.96 & 0.382 & NS & NS & $0.080(\mathrm{~S})$ \\
\hline 42. & 4.14 & 4.11 & 4.08 & 0.935 & NS & NS & NS \\
\hline & 3.98 & 4.20 & 4.22 & 0.357 & NS & NS & NS \\
\hline 44. & 4.39 & 4.13 & 3.92 & 0.012 & NS & NS & NS \\
\hline & 3.89 & 3.93 & 3.75 & 0.459 & NS & NS & NS \\
\hline 45. & 3.59 & 3.28 & 3.25 & 0.208 & NS & NS & NS \\
\hline & 3.49 & 3.46 & 3.96 & 0.003 & NS & NS & NS \\
\hline 46. & 4.07 & 3.82 & 3.80 & 0.342 & NS & NS & NS \\
\hline & 3.65 & 3.43 & 3.51 & 0.653 & NS & NS & NS \\
\hline 47. & 3.05 & 2.82 & 2.84 & 0.460 & NS & NS & NS \\
\hline & 2.64 & 2.46 & 2.18 & 0.018 & NS & NS & NS \\
\hline
\end{tabular}


mobile television. For the latter, only 1.5 per cent innovators (n: 6), 12.1 per cent early adopters (n: 49) and 11.4 per cent early majority (n: 46) were found, contrary to, respectively, 2.6 per cent (n: 7), 14.9 per cent (n: 40) and 24.2 per cent (n: 65) for the mobile news application. Next to 13 respondents not being allocated to an adopter segment due to 'unreliable answering patterns', 160 (39.5 per cent) were considered to be a late majority for mobile television, and 131 (32.2 per cent) as laggards. For the mobile news application, there were 33 unreliables, 96 (35.7 per cent) late majority and 24 (8.9 per cent) laggards.

Owing to the small sizes of the innovator segments in both studies, the innovators and early adopters are grouped into one 'earlier adopters' segment for further analysis. Consequently, the two least innovative segments of late majority and laggards were also grouped into a 'later adopters' segment.

In the ANOVA analysis, determinants are considered as relevant when respondents appear to have an outspoken opinion on them. The items on which the respondents have no opinion are nonrelevant (depicted in grey) (neutral scores of which the mean ranges between 2.60 and 3.40). Means indicating that a segment is strongly agreeing are depicted in green (brighter shade of green when they strongly agree (means $>3.80$ ), a lighter shade of green when they moderately agree (means ranging between 3.41 and 3.80)). Strong disagreement (means $<2.20$ ) is depicted in red, and moderate disagreement (2.20-2.59) in orange. For the regression analysis, only the significant regression weights $(p<0.05)$ are reported in bold. When a determinant was not significantly correlated with the adoption intention, NS is mentioned.

Also in the reporting of the ANOVA as regression results, the cells contain two lines of figures/data. The first line contains the results for the mobile news application, and the second line the results for the mobile television application. The numbers in the left column correspond with the numbers of the items in Table 3.

A first glance at this table immediately indicates several differences between the attitudes or determinants for both innovations. In the average agreement scores for example, it can be noticed that a determinant as 'tangibles' $(14,25)$ is more important for mobile television than for mobile news. Regarding 'reliability' (31), people seem to be more sceptical of mobile news, while the 'perceived control' (46) seems to be higher for this new mobile application. 'Product knowledge' $(19,35)$, on the other hand, is lower for mobile television, etc. With an $R^{2}$ ranging between 0.503 and 0.795 for the earlier adopters and early majority, these 47 'determinant operationalisations' certainly seem to be a good set of variables to explain the variance in the dependent variable 'adoption intention'. Even for the later adopter segments, this $R^{2}$ still ranges between 0.34 and 0.42 . Thus, for both technologies, this set of attitudinal determinant statements explains adoption intentions quite well, but also here there are many differences in the significant determinants for the different innovations and adopter segments. 'Lifestyle compatibility' (39) for example is only significant for the mobile television's innovators, not for mobile news. Also, the 'Cost perception' (1) is only significant in the mobile television case (laggards). 'Trialability' (41) is then significant in both cases, but not for the same segments. Other determinants such as the perceived impact of adoption on one's 'image' (33) were only significant for mobile news' innovators and laggards. Thus, many differences in attitudes exist, as well as when compared over the two cases, as compared over the different adopter segments, which emphasises again the need for a product- and segment-specific approach when preparing the targeting and marketing strategies for these mobile applications.

The combined interpretation of these differences in agreement scores and significant explaining variables allows to provide valuable input in the search for more effective (micro)segment targeting for the introduction of these new mobile services. In the paragraphs, below some of these conclusions are summarised for both technologies.

\section{RESULTS: DETERMINANTS FOR MOBILE NEWS}

\section{Earlier adopters}

The earlier adopters are the only segment that has clear moments of use in mind $(1.84 / 5$ on 
statement 40) and for which the mobile news service is clearly perceived to have more advantages than disadvantages $(3.55 / 5)$ (relative advantage), a finding that is also reflected in the perceived effectiveness (36): only the earlier adopters are (moderately) convinced that mobile news services will make things easier. For the subdimension tangibles, it turns out that the 'look and feel' of new technologies is an important criterion (item 14), and even a decisive predictive factor for the adoption intention of mobile news, although the tangibility of the mobile news application as it exists to date is unsatisfactory. Improving the design and style of the application seems to be an important 'working point' for the future.

The major perceived advantage for these earlier adopters seems to be of a more cognitive nature: impact on their status and being confirmed as an opinion leader. For this segment, it is known that is important to be (continuously) confirmed in their status of opinion leader. Also for mobile news, they expect themselves to be considered as some kind of opinion leader (15), which also explains the significant relation between degree of product knowledge and adoption intention $(19,35)$. Next to that, the forecasted earlier adopters also seem to be high potentials because of the possible impact on their image and prestige (regression 33 and 38). The perceived impact of mobile news adoption on their image, however, is not very high, but this may be due to the unsatisfactory design (25) and lack of outspoken advantages to date.

For the communication and targeting efforts to these earlier adopters, it will certainly be important to keep them well informed (product knowledge (35) important, but could be improved) and to keep in mind that they (item 10) are eager to keep up a certain appearance or to come up to certain expectancy (social pressure). Combined with an emphasis on the userfriendliness of the application - also being a compelling reason to adopt for the earlier adopters (20) - an appeal to these more cognitive arguments seems to be the best approach for targeting earlier adopters. Mobile news adoption may also be framed as compatible with their busy and innovative lifestyle (7) in which the use of such applications is quite 'fun' or enjoyable (4).

\section{Early majority}

There clearly exists a certain interest in the mobile news application among the early majority, but the (relative) advantages are not clear enough $(11,28)$. To date, they still cope with too many thresholds and considerable uncertainty. A first indication of this can be found in the trialability being very important (and a significant driver) to them (item 41). Also in the outspoken perceived risks $(21,23)$, we find this revealed. Targeting efforts towards the early majority will have to work on diminishing the worries about implementation (23) and social disapproval in case of adoption (21). For both items a significant negative impact on adoption intention can be noticed if the perceived risk increases.

Other important issues to keep in mind when approaching this early majority will be their pricesensitivity $(1,5)$ and their worries about the technological compatibility $(30,13)$ : they are less interested in the application if it implies investing in a new mobile device, and they would like the application to be part of a 'larger extensive application package'.

\section{Later adopters}

Even more than for the early majority, technical compatibility and the investment in a new device (item 30, regression weight -0.168 ) really is a significant adoption threshold for the later adopters for mobile news. A more or less surprising 'adoption driver', on the other hand, may be the 'look and feel' of the new application and device. Tangibles, in other words, can also be an important argument for these later adopters, but to date it is not sufficiently focussed upon in the current application of mobile news (25). Improving the design and style seems to be an important 'working point' for the future.

The novelty of the mobile news application makes it obvious that the respondents have not seen many people in their environment who use mobile news services (17). Seeing more people using it, however, would help the later adopters 
reduce their uncertainty about the innovation. Seeing more people in their environment significantly increases their adoption intention. Even a 'vicarious trial' (no physical trial of the application, but 'looking' at how others use it) (28) would be valuable for them.

For the later adopters, it is striking that 'too much services under one umbrella' might have a negative impact on their adoption intention (cf. regression item 29). The challenge is to work on a few mobile news services with a clear relative advantage, rather than a portfolio of multiple services lacking a clear advantage and risking having a negative impact on the adoption intentions of later adopters. Contrary to the earlier adopters, a communication emphasising the impact of mobile news adoption on their image would have a negative impact on the adoption intention of the later adopters (33).

\section{RESULTS: DETERMINANTS FOR MOBILE TELEVISION}

\section{Earlier adopters}

When it comes to the presentation of mobile television to its potential earlier adopters, attention will have to be paid to its tangibility (look and feel) and a confirmation of their status, opinion leadership and 'techie' image. Also, the ANOVA and the regression analysis (14) reveal that the look and feel or the design of the product (tangibility) is a significant adoption determinant. The significant relation between adoption intention and observability/visibility (regression item 12) indicates that mobile television may have a certain appeal to the earlier adopters to 'show off' (despite the lower mean score in the ANOVA analysis, which may be due to socially desirable answering). A similar conclusion can be made with regard to Lifestyle Compatibility (39), Image/Prestige (38), Result demonstrability/communicability (24) and Opinion leadership (15). Although the early adopters do not explicitly admit the importance of these determinants in relation to their adoption decision, it seems wise to incorporate these aspects into the targeted introduction and communication strategies, since the regression reveals a positive impact. For example by positioning mobile television as a 'high-tech gadget' fitting a busy lifestyle, stressing the design of the device, etc. Related to this, it might also be considered to position mobile television as quite high-tech and complex. Although the earlier adopters do not perceive it as complex (29), it is striking that a higher complexity perception makes adoption of mobile television even more attractive to them (cf. regression).

The lower mean score and significant regression weight for product knowledge (19) indicates that also the 'informing communication' cannot be neglected in the earlier adopters, and in the answers on item 27 some kind of uncertainty-reduction behaviour might be detected. Buying from a well-known and reliable brand should give them more certainty. Also, the high mean score (4.18) on physical trialability (41) reveals some kind of insecurity among earlier adopters. They certainly want to try it out before adopting.

This does not mean, however, that too much emphasis should be placed on the userfriendliness of the technology: complexity drives the earlier adopters to adopt the technology (see discussion above), they are keen on high-tech gadgets and features and they are confident about themselves when it comes to figuring out how an application or technology works, etc (Control/selfefficacy) (46). The ANOVA analysis also indicates that attention should be paid to the advantages of mobile television and usage moments (relative advantage) (40), enjoyment (4) and price (cost) (5). Even innovators and early adopters are worried that mobile television will be too expensive for many people.

\section{Early majority}

For the early majority segment, none of the determinants appears to be a real driver (or threshold) for adoption in the regression analysis. The results from the ANOVA analysis, however, confirm that the early majority is insecure about its adoption intention. To resolve this insecurity, they would rather choose a well-known brand (marketing strategy, 26). In line with this, they feel a need for trialability (physical (41) and 
vicariousness (28)). Compared to the earlier adopters, the early majority is also less convinced of the relative advantages of mobile television $(11,40)$. But as for the innovators, they do perceive some enjoyment in the use of mobile television (4).

With regard to the issue of compatibility, the early majority prefers not to invest in a new device and is only interested when mobile television subscription is part of other mobile services. Also, the look/feel (tangibles) $(24,15)$ and cost $(1,5,22)$ of the device/service should not be neglected when targeting this specific segment. As this segment has a limited product knowledge (19) of mobile television, they certainly also need additional information. Whereas we saw that the early adopters are rather sensitive to social, image, prestige, observability ... determinants, the early majority rather focuses (uncertainty-reduction) on product-related, financial, technical ... aspects regarding mobile television.

\section{Later adopters}

When taking into account the significant drivers and thresholds from the regression analysis, we can conclude that later adopters clearly do not see a relative advantage (item 11) in mobile television, which is affirmed by the low perceived effectiveness (36) and the lack of perceived enjoyment (4) in using mobile television. Another important threshold seems to be the cost (regression item 1).

As with the other two adopter segments, later adopters express some kind of uncertainty about mobile television, which translates into the need for trialability, physical (S41) as well as vicariousness (S28).

When taking into account the distinctive means on certain items that are, however, not linked to a significant driver (or threshold), we can see that the later adopter's noninterest in mobile television is not due to a general negative attitude towards ICT (optimism, 44 and 45). Lifestyle compatibility $(7,39)$ and observability $(12$, 17), however, seem to be totally unimportant for later adopters, something that is confirmed in the equally low score for network externalities (37). It is remarkable that even the later adopters do not think that mobile television is a complex technology (complexity 8, 20, 29). They even consider themselves perfectly capable of dealing with mobile television without help (control 23,46).

In short, later adopters believe that they are capable of using the mobile television technology, but they do not think mobile television is fun, do not see a relative advantage and think it will be too expensive. Mobile television does not fit in with their lifestyle, nor do they feel it will enhance their social image or prestige.

\section{CONCLUSION}

Today's rapidly evolving mobile ICT environment confronts suppliers with new challenges. Two of them are related to the quest for more efficient targeting/marketing strategies since 'inefficient marketing' is often blamed for the majority of the increasing number of failures in this environment:

a. Through which paths can I reach the target audience(s) more efficiently?

b. With which messages can I reach the target audience(s) more efficiently?

Focusing on the second challenge in this paper, we learned that more efficient marketing involves more segment- and product-specific messages, and that the acquisition of an insight into attitudinal adoption determinants is key to formulate those messages. The problem, however, lies in the fact that the literature, models and studies on these determinants are very scattered and fragmented. Therefore, in the first instance, we conducted a meta-analysis on these works, which resulted in a comprising determinant model containing 19 determinants. In order to measure them, a battery of 47 Likert statements was developed, and applied in two case studies on the attitudes towards mobile news (n: 269) and mobile television (n: 405) adoption. A brief extract of some of the results from both studies illustrates how the crossing of these attitudes with 'segmentation forecasts ${ }^{118}$ for both innovations can provide mobile marketers with valuable input to set up more efficient (micro)segment targeting and marketing campaigns, or to formulate the correct 
messages to reach the target audience(s) more efficiently. These messages can be communicated through the 'traditional' communication paths, but it seems evident that more and more newly developed 'mobile communication paths' will become available to communicate those messages more efficiently.

In order to identify the segments to whom these messages should be communicated, the user research conducted needs to comprise sufficient profiling variables with which the forecasted adopter segments can be crossed. In the case of mobile television for example, earlier adopters appeared to be young and heavy television watchers (of specific entertainment channels as VT4 (SBS)). In general, the earlier adopters for mobile television were still studying or unemployed, lived alone or still lived with their parents and came from a lower social class. They clearly possessed more than average mobile multimedia technology like advanced MP3-players, digital cameras and portable DVD-players. They were also the only segment to use their (usually advanced) mobile phones for multi-media applications like taking pictures, making movies, listening to music, playing games, etc. In the 'mobile news' study, the comparison between adopter segments revealed large differences in media use and news interest. Although the earlier adopters appeared to be heavy media users, they mostly consume media for leisure purposes and to stay up to date with local news, with an outright preference for specific news providers. Referring to the mentioned challenges, it is evident that such profiling information is a key to determine the best paths to target the audience more efficiently. Once these paths are determined, the segmented insight into adoption determinants should help to formulate the messages to target the audience(s) more efficiently.

\section{Acknowledgments}

This work was supported by the IBBT ROMAS (Research on Mobile Applications and Services) project, co-funded by the IBBT (Interdisciplinary institute for BroadBand Technology), a research institute founded by the
Flemish Government in 2004, and the involved companies and institutions. Among the latter, we especially thank I-city.

\section{References}

1 Moreau, C. P., Lehmann, D. R. and Markman, A. B. (2001) 'Entrenched knowledge structures and consumer response to new products', Journal of Marketing Research, Vol. 28 (February), pp. 14-29.

2 Van Riel, A. C. R., Lemmink, J. and Ouwersloot, H. (2004) 'High-technology service innovation success: A decision-making perspective', Journal of Product Innovation Management, Vol. 21, No. 5, pp. 348-359.

3 Cooper, R. G. (2003) 'Profitable product innovation: The critical success factors', in Shavinina, L.V. (ed.) 'The International Handbook on Innovation', Pergamon, Elsevier, Oxford, UK, pp. 139-157.

4 Lee, E. -J., Lee, J. and Schumann, D. W. (2002) 'The influence of communication source and mode on consumer adoption technological innovations', The Journal of Consumer Affairs, Vol. 36, No. 1, pp. 1-27.

5 Waarts, E., Van Everdingen, Y. M. and Van Hilligersberg, J. (2002) 'The dynamics of factors affecting the adoption of innovations', The Journal of Product Innovation Management, Vol. 19, No. 6, pp. 412-423.

6 Montaguti, E., Kuester, S. and Robertson, T. S. (2002) 'Entry strategy for radical product innovations: A conceptual model and propositional inventory', International Journal of Research in Marketing, Vol. 19 (1), pp. 21-42.

7 McBurney, P., Parsons, S. and Green, J. (2002) 'Forecasting market demand for new telecommunications services: An introduction', Telematics and Informatics, Vol. 19, No. 3, pp. 225-249.

8 Choi, H., Choi, M., Kim, J. and Yu, H. (2003) 'An empirical study on the adoption of information appliances with a focus on interactive TV', Telematics and Informatics, Vol. 20, No. 2, pp. 161-183.

9 Baldwin, T. F., Stevens McVoy, D. and Steinfeld, C. (1996) 'Convergence. Integrating Media, Information \& Communication', Sage Publications, Thousand Oaks.

10 Van Dijk, J. (1999) 'The Network Society. Social Aspects of New Media', Sage, London, Thousand Oaks, New Delhi.

11 Steinbock, D. (2005) 'The Mobile Revolution', Kogan Page, London.

12 Netsize (2007) 'The Netsize guide 2007. Convergence: Everything's going mobile”, Informa Telecoms \& Media, Vol. 10, pp. 1-159.

13 Anderson, C. (2005) 'Why the Future of Business is Selling Less or More', Hyperion, New York.

14 'Mobile internet' was already promised with technologies such as WAP and GPRS in the 1990s, but only the current technologies (UMTS, HSDPA) have really been able to live up to that promise.

15 Cf. worldwide mobile television trials in Finland (2005), The Netherlands (2005), UK (2006), Switzerland (2006) or commercial roll-outs such as in Italy or South Korea.

16 Sutherland, F. (1999) 'Remote overload: Too much too soon', Cable and Satellite Europe, issue, Vol. 187 (July), pp. 46-49.

17 Thomson, S. (2002) 'Set-tops: The next generation', Cable and Satellite Europe, Vol. 216 (January/February), pp. 16-19. 
18 Bergman, S., Frissen, V. and Slaa, P. (1995) 'Gebruik en betekenis van de telefoon in het leven van alledag', in Rathenau Institute (ed.) 'Toeval of noodzaak? Geschiedenis van de overheidsbemoeienis met de informatievoorziening', Meboprint, Fatima Reeks, Amsterdam, pp. 277-325.

19 Atkin, J. A., Neuendorf, K., Jeffres, L. W. and Skalski, P. (2003) 'Predictors of audience interest in adopting digital television', The Journal of Media Economics, Vol. 16, No. 3, pp. 159-173.

20 Plouffe, C. R., Vandenbosch, M. and Hulland, J. (2001) 'Intermediating technologies and multi-group adoption: A comparison of consumer and merchant adoption intentions toward a new electronic payment system', The Journal of Product Innovation Management, Vol. 18 (2), pp. 65-81.

21 Atkin, D., Jeffres, L. and Neuendorf, K. (1998) 'Understanding internet adoption as telecommunications behavior', Journal of Broadcasting and Electronic Media, Vol. 42, No. 4, pp. 475-490.

22 Leung, L. (1998) 'Lifestyles and the use of new media technology in urban China', Telecommunications Policy, Vol. 22, No. 9, pp. 781-790.

23 Moore, G. A. (1999) 'Crossing the Chasm. Marketing and Selling Technology Products to Mainstream Customers', 3rd edn, Capstone Publishing, Oxford.

24 Easingwood, C. J. and Koustelos, A. (2000) 'Marketing high technology: Preparation, targeting, positioning, execution', Business Horizons, Vol. 43, No. 3, pp. 27-34.

25 Silverstone, R. (1996) 'Future imperfect: Information and communication technologies in everyday life', in Dutton, W.H. (ed.) 'Information and Communication Technologies: Visions and Realities', Oxford University Press, Oxford, pp. 217-231.

26 Lister, M., Dovey, J., Giddings, S., Grant, I. and Kelly, K. (2003) 'New Media: A Critical Introduction', Routledge, London/New York.

27 Kotler, P. (2002) 'Marketing Management', 11th edn, PrenticeHall, Upper Saddle River.

28 Tvede, L. and Ohnemus, P. (2001) 'Marketing Strategies for the New Economy', John Wiley \& Sons, Chichester.

29 During the launch of the latest Christina Aguilera album for example, Belgian consumers walking by a billboard promoting that album could download ring tones through a Bluetooth connection (for free).

30 Mobile users can create their own profile in their mobile (eg interested in Spiderman comics or Chanel no.5) and when one is walking by a shop having a promotion on those products you are alerted on the mobile device.

31 Windahl, S., Signitzer, B. and Olson, J. T. (1992) 'Using Communication Theory: An Introduction to Planned Communication', Sage, London.

32 de Vos, L. (2000) 'Searching for the holy grail. Images of interactive television', $\mathrm{PhD}$ dissertation, EMMA European Media Masters of Arts, Department of Art, Media and Technology, University of Utrecht.

33 Daghfous, N., Petrof, J.V. and Pons, F. (1999) 'Values and adoption of innovations: A cross-cultural study', The Journal of Consumer Marketing, Vol. 16, No. 4, pp. 314-331.

34 Oxley, M. and Nancorrow, C. (2003) 'Measuring diffusion: Fast tracking new products', Admap, Vol. 436 (February), pp. 40-43.

35 Fill, C. (1995) 'Marketing Communications. Frameworks, Theories and Applications', Prentice-Hall, London.

36 Inconsistency on two levels: (1) inconsistent with the literature assumptions: assumptions (eg innovators being typically male) are not always confirmed anymore and (2) inconsistency between technologies: some assumptions are confirmed for one technology, and others are confirmed for other technologies.

37 Chen, L. D., Gillenson, M. L. and Sherrel, D. L. (2002) 'Enticing online consumers: An extended technology acceptance perspective', Information \& Management, Vol. 39, No. 8, pp. 705-719.

38 Lin, C. A. (1994) 'Exploring potential factors for home videotext adoption', in Hanson, J. (ed.) 'Advances in Telematics', Vol. 2, Ablex, New York, pp. 111-121.

39 Jeffres, L. W. and Atkin, D. (1996) 'Predicting use of technologies for communication and consumer needs', Journal of Broadcasting E Electronic Media, Vol. 40, No. 3, pp. 318-330.

40 Eastin, M. S. (2002) 'Diffusion of e-commerce: An analysis of the adoption of four e-commerce activities', Telematics and Informatics, Vol. 19, No. 3, pp. 251-267.

41 LaRose, R. and Atkin, D. (1988a) 'Satisfaction, demographic and media environment predictors of cable subscription', Journal of Broadcasting and Electronic Media, Vol. 32 (4), pp. 403-413.

42 Rogers, E. M. (2003) 'Diffusion of Innovations', 5th edn, The Free Press, New York.

43 Rogers, E. M. (1983) 'The Diffusion of Innovations', 3rd edn, The Free Press, New York.

44 Trujilo, M. F. (2003). Diffusion of ICT Innovations for Sustainable Human Development Based on the Rogers Social Diffusion of Innovations Model, http://www.payson.tulane.edu/research/ E-Difflnnova/diff-prob.html, consulted 15/04/2003.

45 Sameer, V. (1999) 'Diffusion and adoption of multicasting: Role of implicit versus explicit communication initiation methods', White Paper, J Mack Robinson College of Business, Georgia State University.

46 Karahanna, E., Straub, D. W. and Chervany, N. L. (1999) 'Information technology adoption across time: A cross-sectional comparison of pre-adoption and post-adoption beliefs', MIS Quarterly, Vol. 23, No. 2, pp. 183-213.

47 Davis, F. D. (1989) 'Perceived usefulness, perceived ease of use, and user acceptance of information technology', MIS Quarterly, Vol. 13, No. 3, pp. 319-340.

48 Chang, M. K. and Cheung, W. (2001) 'Determinants of the intention to use internet/WWW at work: A confirmatory study', Information \& Management, Vol. 39, No. 1, pp. 1-14.

49 Servaes, J. and Heinderyckx, F. (2002) 'The 'new' ICTs environment in Europe: Closing of widening the gaps', Telematics and Informatics, Vol. 19, No. 2, pp. 91-115.

50 Heres, J., Mante-Meijer, E. and Pires, D. (2002) 'Factors influencing the adoption of broadband mobile internet', TIC, Vol. 9, pp. 51-79.

51 Dowling, G. R. (1999) ‘Consumer innovativeness', in Earl, P.E., Kemp, S. (eds) 'The Elgar Companion to Consumer Research and Economic Psychology', Elgar, Cheltenham, pp. 111-115.

52 Brown, I., Cajee, Z., Davies, D. and Stroebel, S. (2003) 'Cell phone banking: Predictors of adoption in South Africa - an exploratory study', International Journal of Information Management, Vol. 23, No. 5, pp. 381-394.

53 Bouwman, H., Van Dijk, J., Van Den Hooff, B. and Van De Wijgaert, L. (2002) 'ICT in organisaties. Adoptie, implementatie, gebruik en effecten', Boom, Amsterdam.

54 Guiltinan, J. P. (1999) 'Launch strategy, launch tactics, and demand outcomes', Journal of Product Innovation Management, Vol. 16, No. 6, pp. 509-529.

55 Meijer, G. R., Samuels, J. and Terpstra, F. (2002) 'Modeling user acceptance and technology adoption: Is there a case for value added services?', http://carol.wihs.uva.nl/ ftrtpstra/ 
its-2002,Proceedings of the 9th World Congress on Intelligent Transport Systems, Chicago, Illinois, October 2002.

56 Easingwood, C. J. and Lunn, S. O. (1992) 'Diffusion paths in a high-tech environment - Clusters and commonalities', RED Management, Vol. 22, No. 1, pp. 69-80.

57 Complexity issues, for example, are not tackled in the beginning of introduction strategies, but later when majority or laggard adoption is at stake (by emphasising the user friendliness of the innovation). In the beginning, when innovator and early adopter adoption is at stake, emphasis is more on the innovativeness or trialability of the innovation. Illustrative for the latter are the trial devices in cinemas at the introduction of Sony's PSP.

58 Fishbein, M. A. (1967) 'Readings in Attitude Theory and Measurement', Wiley, New York.

59 Fishbein, M. A. and Ajzen, I. (1975) 'Belief, Attitude, Intention and Behavior: An Introduction to Theory and Research', Addison-Wesley, Reading, MA.

60 Davis, F. D. (1986) 'A Technology Acceptance Model for Empirically Testing New End-User Information Systems: Theory and Results, onuitgegeven doctoraatsverhandeling', MIT Sloan Management School, Cambridge.

61 Ajzen, I. (1991) 'The theory of planned behavior', Organizational Behavior and Human Decision Processes, Vol. 50, No. 2, pp. 179211.

62 Taylor, S. and Todd, P. (1995) 'Decomposition and crossover effects in the theory of planned behavior: A study of consumer adoption intentions', International Journal of Research in Marketing, Vol. 12, No. 2, pp. 137-155.

63 Holak, S. L. and Lehmann, D. R. (1990) 'Purchase intentions and the dimensions of innovation: An exploratory model', Journal of Product Innovation Management, Vol. 7 (1), pp. 59-73.

64 Busselle, R., Reagan, J., Pinkleton, B. and Jackson, K. (1999) 'Factors affecting internet use in a saturated-access population', Telematics and Informatics, Vol. 16, No. 1-2, pp. 45-48.

65 Randolph, C. (1999) 'Why do we hate Microsoft and still use Word?', Proceedings of the 10th Australasian Conference on Information Systems, Australia, Toleman University of Southern Queensland, Toowoomba, pp. 736-748.

66 Hadjimanolis, A. (2003) 'The barriers approach to innovation', in Shavinina, L.V. (ed) 'The International Handbook on Innovation', Pergamon, Elsevier, Oxford, UK, pp. 559-573.

67 Studies and theories in the areas of communication, marketing as well as social psychology (cf. references Table 2).

68 Fliegel, F. C. and Kivlin, J. E. (1966) 'Attributes of innovations as factors in diffusion', American Journal of Sociology, Vol. 72 (November), pp. 235-248.

69 Cestre, G. and Darmon, R.Y. (1998) 'Assessing consumer preferences in the context of new product diffusion', International Journal of Research in Marketing, Vol. 15, No. 2, pp. 123-135.

70 Veryzer, R. (1998) 'Key factors affecting customer evaluation of discontinuous new products', Journal of Product Innovation Management, Vol. 15, No. 2, pp. 136-150.

71 Chan-Olmsted, S. M. and Gershon, R. A. (2001)

'Telecommunications marketing', in Gershon, R.A. (ed.)

'Telecommunications Management. Industry Structures and

Planning Strategies', Lawrence Erlbaum Associates, Mahwah, New Jersey, London, pp. 281-304.

72 Punie, Y. (2000) 'Domesticatie van informatie- en communicatietechnologie. Adoptie, gebruik en betekenis van media in het dagelijkse leven: Continue beperking of discontinue bevrijding?PhD dissertation, Vakgroep Communicatiewetenschappen, Vrije Universiteit Brussel.
73 Frambach, R. T. and Hillebrand, B. (1994) 'Diffusietheorie. Overzicht, kritiek en implicaties', Tijdschrift voor Marketing, Vol. 28, No. 12, pp. 37-42.

74 Igbaria, M., Parasuraman, S. and Baroudi, J. J. (1996) 'A motivational model of microcomputer usage', Journal of Management Information Systems, Vol. 13, No. 1, pp. 127-143.

75 Mundorf, N. and Westin, S. (1996) 'Adoption of information technology: Contributing factors', in Dholakia, R.R., Mundorf, N., Dholakia, N. (eds) 'New Infotainment Technologies in the Home. Demand-Side Perspectives', Publisher: Lawrence Erlbaum Associates, Mahwah, New Jersey, pp. 157-172.

76 Ram, S. and Sheth, J. N. (1989) 'Consumers resistance to innovations: The marketing problem and its solutions', Journal of Consumer Marketing, Vol. 6, No. 2, pp. 5-14.

77 Dodgson, M. (2000) 'The Management of Technological Innovation. An International and Strategic Approach', University Press, Oxford.

78 Dearing, J. and Meyer, G. (1994) 'An exploration tool for predicting adoption decisions', Science Communication, Vol. 16, No. (1), pp. 43-57.

79 Dowling, G. R. (1978) 'Innovativeness: the concept and its measurement', Journal of Consumer Research, Vol. 4 (March), pp. 229-242.

80 Hirschman, E. C. (1980) 'Innovativeness, novelty seeking, and consumer creativity', Journal of Consumer Research, Vol. 7, No. 3, pp. 283-295.

$81 \mathrm{Li}$, S. S. (2004) 'Examining the factors that influence the intentions to adopt internet shopping and cable television in Taiwan', New Media \& Society, Vol. 6, No. 2, pp. 173-193.

82 Lin, C. A. and Jeffres, L. W. (1998) 'Factors influencing the adoption of multimedia cable technology', Journalism and Mass Communication Quarterly, Vol. 75, No. 2, pp. 341-352.

83 Marsden, P.V. (1981) 'Introducing influence processes into a system of collective decisions', American Journal of Sociology, Vol. 86, No. 6, pp. 1203-1235.

84 Woolgar, S. (1996) 'Technologies as cultural artefacts', in Dutton, W.H. (ed.) 'Information and Communication Technologies:Visions and Realities', Oxford University Press, Oxford, pp. 87-101.

85 Gatignon, H. and Robertson, T. S. (1989) 'Diffusion of innovation', EIASM White Paper, Brussels, Belgium.

86 Fichman, R. G. and Kemerer, C. F. (1997) 'The assimilation of software process innovations: An organizational learning perspective', Management Science, Vol. 43, No. 10, pp. 1345-1363.

87 Parasuraman, A. and Colby, C. L. (2001) 'Techno-Reading Marketing: How and Why Your Customers Adopt Technology', Free Press, New York.

88 Wei, R. (2001) 'From luxury to utility: A longitudinal analysis of cell phone laggards', Journalism and Mass Communication Quarterly, Vol. 78, No. 4, pp. 702-719.

89 Neuendorf, K., Atkin, D. and Jeffres, L. (1998) 'Understanding adopters of audio information innovations', Journal of Broadcasting and Electronic Media, Vol. 42, No. 1, pp. 80-94.

90 Moore, G. C. and Benbasat, I. (1991) 'Development of an instrument to measure the perceptions of adopting an information technology innovation', Information Systems Research, Vol. 2, No. 3, pp. 192-222.

91 Sheth, J. N., Newman, B. I. and Gross, B. L. (1991) 'Why we buy what we buy: A theory of consumption values', Journal of Business Research, Vol. 22, No. 2, pp. 159-170.

92 Talukdar, D., Sudhir, L. and Ainslie, A. (2002) 'Investigating new product diffusion across products and countries', Marketing Science, Vol. 21, No. 1, pp. 97-114. 
93 Jiang, P. (2002) 'Exploring consumers' willingness to pay for online customisation and its marketing outcomes', Journal of Targeting, Measurement and Analysis for Marketing, Vol. 11, No. 2, pp. $168-183$.

94 Ricci, A. (2000) 'Measuring information society. Dynamics of European data on usage of European data on usage of information and communication technologies in Europe since 1995', Telematics and Informatics, Vol. 17, No. 1-2, pp. 141-167.

95 Lennstrand, B. (1998a) 'Diffusion of information and communication technology to households: How come it goes so slowly when it goes so fast?', http://www.fek.su.se/home/bl/ Diffusion/RapidSlow.PDF,paper presented at 12th Biennal ITS Conference, Stockholm, 21st-24th June, 1998, geraadpleegd op 2002-08-05, pp. 1-18.

96 Venkatesh, V. (2000) 'Determinants of perceived ease of use: Integrating control, intrinsic motivation, and emotion into the technology acceptance model', Information Systems Research, Vol. 11, No. 4, pp. 342-365.

97 Lee, J. and Baek, S. I. (2001) 'Adoption of internet technologies in small business', http://ijdm.digital.re.kr/issue-1/sbaek. pdfInternational Journal of Digital Management, Issue 1, 2001 : 1-14, laatst geraadpleegd op 12/10/2003.

98 Pajo, K. (2000) 'Individual characteristics and the adoption of technology in distance education?', Proceedings of the International Conference Distance Education: An Open Question?, Adelaide, Australia, September 2000.

99 Lau, A., Yen, J. and Chau, P. Y. K. (2001) 'Adoption of on-line trading in the Hong Kong financial market', Journal of Electronic Commerce Research, Vol. 2, No. 2, pp. 58-65.

100 Steenkamp, J. -B. E. M. and Gielens, K. (2003) 'Consumer and market drivers of the trial probability of new consumer packaged goods', Journal of Consumer Research, Vol. 30 (December), pp. 368-384.

101 Jankowski, N. and Van Selm, M. (2001) 'ICT en samenleving. Vier terreinen voor empirisch onderzoek', in Bouwman, $\mathrm{H}$. (ed.) 'Communicatie in de Informatiesamenleving', Lemma, Utrecht, pp. 217-249.

102 Bouwman, H. and De Jong, A. (1996) 'Predicting consumer adoption of information technologies', in Jankowski, N.W., Hanssen, L. (eds) 'Contours of Multimedia: Recent Technological, Theoretical And Empirical Developments', Libbey, London, pp. 160-170.

103 Sultan, F., Farley, J. U. and Lehmann, D. R. (1990) 'A metaanalysis of diffusion models', Journal of Marketing Research, Vol. 27 (February), pp. 70-77.

104 Gatignon, H. and Robertson, T. S. (1985) 'A propositional inventory for new diffusion research', Journal of Consumer Research, Vol. 11 (March), pp. 849-867.

105 Other risk dimensions such as 'financial risk' and 'social risk' are covered by determinants such as perceived cost and social influence. Reliability is more about 'performance risk'.

106 Wright, M. and Chariett, D. (1995) 'New product diffusion models in marketing: An assessment of two approaches', Marketing Bulletin, Vol. 6, pp. 32-41.

107 McMeekin, A. and Tomlinson, M. (1998) 'Diffusion with distinction', Futures, Vol. 30 9, pp. 873-886.

108 MICT (Media \& ICT, www.mict.be), IBBT (Interdisciplinary Institute for BroadBand Technology, www.ibbt.be).
109 ROMAS: Research On Mobile Applications and Services.

110 de Marez, L. (2006) 'Diffusie van ICT-innovaties: accurater gebruikersinzicht voor betere introductiestrategieën', $\mathrm{PhD}$ dissertation, vakgroep communicatiewetenschappen, Universiteit Gent, oktober 2006.

111 de Marez, L. and Verleye, G. (2004a) 'ICT-innovations today: Making traditional diffusion patterns obsolete, and preliminary insight of increased importance', Telematics and Informatics, Vol. 21, pp. 235-260.

112 de Marez, L. and Verleye, G. (2004b) 'Innovation diffusion: The need for more accurate consumer insight. Illustration of the PSAP-scale as a segmentation instrument', The Journal of Targeting, Measurement and Analysis for Marketing, Vol. 13, No. 1, pp. 32-49.

113 Verleye, G. and de Marez, L. (2005) 'Diffusion of innovations: Successful adoption needs more effective soft-DSS driven targeting', The Journal of Targeting, Measurement and Analysis for Marketing, Vol. 13, No. 2, pp. 140-155.

114 In Goldsmith and Hofacker's Domain Specific Innovativess (DSI) scale for example (6 statements), we find trialability translated into the statement 'I will not buy a new ... if I haven't tried it yet'. ${ }^{112}$ In Moore and Benbasat's scale 'I believe that ... is cumbersome to use' operationalises the complexity determinant, ${ }^{88} \ldots$ Other operationalisations were found in Technology Readiness Scale of Parasuraman and Colby, ${ }^{85}$ the PIITscale of Agarwal and Prasad, ${ }^{113}$ or the many variants of diffusion theory-based determinant models ${ }^{20,63,101,48} \ldots$ ) and social psychology-based models $\left.{ }^{8,62}, \ldots\right)$.

115 Goldsmith, R. E. and Hofacker, C. (1991) 'Measuring consumer innovativeness', Journal of the Academy of Marketing Science, Vol. 19, No. 3, pp. 209-222.

116 Agarwal, R. and Prasad, J. (1997) 'The role of innovation characteristics and perceived voluntariness in the acceptance of information technologies', Decision Sciences, Vol. 28, No. 3, pp. 557-582.

117 Each of these four focus group sessions included eight persons (four male, four female), equally spread over the age categories $-20,21-30,31-40$ and $41-50$. Each of the focus group sessions had a similar structure. The respondents were invited for a 'broad talk on ICT'. In the first instance, people were asked to talk freely about two technologies most were assumed to be familiar with: mobile phones and DVD players. In this first phase of the session, the moderator's only task was to steer the discussion in the direction of drivers and thresholds for (non)-adoption (without keeping the 'list of 19' in mind). Only in the second hour of the focus group discussions was the model of 19 determinants used as a 'thread'. Each of the 19 determinants was explained to the respondents, and by means of a back coupling to the discussion of the previous hour of the group discussion, there was a strive towards 'consensus operationalisation' and 'good comprehension' for each of the determinants'. Only when a consensus operationalisation was reached for the familiar technologies of DVD and mobile phones, did the third and final phase start: the operationalisation for the new innovations.

118 Prior-to-launch forecasts in terms of the potential innovator, early adopters, majority and laggards segments for both mobile services. 